\title{
On the Reform of Salary System in Colleges and Universities based on the Reform of Pension Insurance System
}

\author{
Shufeng $\mathrm{Ni}$ \\ Jilin Agricultural University \\ 512375850@qq.com
}

Keywords: Pension insurance system; Colleges and universities; Salary system

\begin{abstract}
At present, the pension insurance system in China's public institutes is being gradually reformed, and as a part of public institutes, colleges and universities' salary system should also be reformed once the pension insurance system of public institutes needs to be reformed so that the salary system can play its due role. Aiming at this, this paper analyzes the problems existing the China's current college and university salary system against the background of reforming pension salary system as well as strategies for reform.
\end{abstract}

\section{The Necessity of Reforming Pension Insurance System}

In all of China's social security system, pension insurance system can be said to be very important, for which our country has been committed to the reform of the institution of pension insurance system. Talking about the reform of the endowment insurance system in China can be traced back to the nineties of the last century, at that time some of China's provinces and cities began for old-age insurance system reform, to study for the institutions of the endowment insurance system reform of the way. At that time, the reform of the old-age insurance system in these provinces and municipalities have effect, however, China's provinces and cities very much, the basic situation of each of the provinces and cities have great differences exist, which led to in the reform practice, simply cannot be consistent with the old-age insurance system, which can avoid caused by unfair distribution of problems, is not conducive to building a harmonious socialist society. In addition, to reform the institutions endowment insurance system in the process, also appeared in a series of problems, such as with the relevant laws and regulations is not perfect, the most obvious is the "dual track" exists, is not conducive to the endowment insurance system reform.

However, it is very necessary to reform college and university pension insurance system, or there will be problems in the following three aspects:

First of all, it is not conducive to the reform of personnel system. In recent years, many colleges and universities in our country are constantly exploring new personnel system and salary system in the to be more in line with the actual situation and the development direction in the future, expect can no longer be constraints on the system and mechanism, which can effectively promote the high school level of education. However, in reality, the pension system and the enterprise is completely different, for college retirees, the benefits are entirely borne by the University, which is exacerbated by the pressure of the university. In addition, for a lot of colleges and universities, the staff, the self is the existence of the unit, rather than a social person. In this case, if the personnel system reform, then it will make the university staff, especially the university teachers to the community or business, will reduce the enthusiasm of the work of College teachers. It can be said that the pension system is not perfect, it will not be able to carry out the reform of the personnel system.

Secondly, it is not conducive to connecting the social insurance system. In order to deepen the reform of the personnel system of our country, it is essential to reform the salary system of colleges and universities, that is, to re-determine the distribution system. It can be said that only in this way can we effectively connect the social security system. However, the current salary system reform in colleges and universities is more difficult, mainly because pension system reform is not thorough enough.

Finally, it is not conducive to reforming the distribution system. In our country's major colleges 
and universities, there are specialized in the retired Department, the Department is responsible for the management of University retirees, one of which includes the salary of retired personnel. Retired staff salaries are paid on time into the personal account, these wages are composed of two parts, one part is provided by the government, probably accounted for $30 \%$, the remaining $70 \%$ is provided by the university. If we do not reform the pension insurance system, it is not able to improve the salary level of retirees in Colleges and universities, but also in this case the financial burden of colleges and universities will be increased. Universities in order to enhance the financial income, may be involved in other industries, which will not be conducive to the role of education in Colleges and universities. But if the salary of University retirees from the government issued, then it cannot be achieved its support. It can be said that with the reform of social security system, if not for the pension system reform, then will not be conducive to the reform of the distribution system.

At present, performance salary is gradually implemented at many places in China. Consequently, the pensions of retired persons have been greatly increased with a very rapid growth rate. Compared with existing staffs at the same unit, the growth speed is improved a lot, thus many existing staffs lack enthusiasm at work. Due to these problems, it is necessary to reform pension insurance system at colleges and universities.

\section{Reform of Pension Insurance System as well as its Influence and Challenges on Chinese Colleges and Universities' Salary System}

Reform of Pension Insurance System. Through the reform of the pension insurance system, for institutions, social pooling and individual account are organically combined together. That is to say endowment insurance to the units and individuals to pay, the proportion of units to pay in $20 \%$, the base pay is unit total wages; proportion paid by the individuals in $8 \%$, the base pay is to obtain the actual personal wages, and the amount paid by the individuals is used to establish the basic old-age insurance personal accounts. Of course, in different places of the university staff wages are also different, if personal wages must be higher than the local average wage of $300 \%$, then high does not need to pay as the cardinality of the endowment insurance; if personal wages are even lower than $60 \%$ of the local average wage, then according to $60 \%$ of the local average wage level as endowment insurance base pay.

Influence of Pension Insurance System Reform on Colleges and Universities' Salary System. The reform of the old age insurance system also has a far-reaching impact on the salary system of colleges and universities. With the reform of the pension system, colleges and universities must reform the salary system so that they can meet the needs of the pension system. The impact of pension system reform on the salary system of colleges and universities is mainly reflected in the following aspects:

First, influence colleges and universities' salary system structure. For the university staffs, especially for teachers, they basically participate in social security, that is, in accordance with the provisions of the law of our country to pay the appropriate pension insurance. University teachers' pension insurance is divided into two parts, a part of the individual to pay, there is a part of the university to pay. Local average wage of $60 \%$ to $300 \%$ pay individual interval, to pay $8 \%$ of the real wages; the in addition to pay old-age insurance for teachers, should also establish occupational pension, occupational pension is a supplementary part of the endowment insurance, the units need to pay $8 \%$ of the total wages, and individuals need to pay $4 \%$ of personal salary. Pension insurance and occupational pension needs to be built together, so the level of old-age insurance system is more abundant, but also to improve the retirement benefits of University retirees, making the overall salary level will not fall.

Second, influence the salary level of college and university staffs. Under the premise of the endowment insurance system reform, also need to the compensation system of the change, the purpose is to in order to ensure the college staff's wages will not decline. Therefore, it is necessary to raise the wages of the staff, improve and to what degree? Minimum also need to be able to make up for the amount of personal pay teachers, so as to ensure that the final salary will not be reduced. On the salary system reform, certain funds need to be invested, and investment funds is paid by the 
state as part of the national budget, which led to into education funds will not be reduced, thus increasing the teachers' retirement pension.

Thirdly, influence pension of college and universities' retired staffs. Before the reform, pensions for retired personnel in colleges and universities rely entirely on in college, but after the reform, the pension is no longer simply rely on colleges and universities, also rely on the personal, thus making social security retirees more reliable.

Challenges Brought by Pension Insurance System Reform to Colleges and Universities' Salary System. With the reform of the pension insurance system, it also brings some challenges to the University. In the current society, countries want to develop, is always inseparable from the role, and colleges and universities is a training place, but the cultivation of talents, is the teacher, is a personal, nature also have material needs. In Colleges and universities, if the set of salary system is very low, then there is no way to attract and retain talent, serious word will also lead to the loss of a large number of outstanding talents, which would not be conducive to the development, is not conducive to the future development of China. And the challenge of the reform of the pension system is the occupational pension. If you give teachers a certain occupational pension, then you can effectively retain talent, but also to attract the talents needed, but for college, this will seriously increase the financial burden. Then is very popular in the international occupational pension, because it can effectively attract talent, but also can play a clean effect, but also will lead to strengthen the mobility of teachers, and it is not conducive to the stability of talent.

\section{Strategies of Reforming Colleges and Universities' Salary System}

Principles of Determining Colleges and Universities' Salary System Reform. In our public institutions endowment insurance system reform background, the university as part of the institution, it should be change for its own compensation system, and the time for change is the need to follow relevant principles, so as to ensure that the new salary system able to meet the actual situation at this stage, able to meet the basic needs of universities and serving officers. First, we need to follow the principle of fairness. Among College jobs are many, even for the same jobs, such as teachers this post, is also divided into $\mathrm{n}$ associate professors, lecturers, etc., can be said that even in the same position, but for the development of universities to make their contribution there are differences and therefore it should follow the principle of equity, to achieve distribution according to work. Second, the need to follow the principle of difference. Although there are universities, colleges and universities but each geographical location and the economic environment is different, so the colleges and universities in the development of staff emoluments, when according to local real level. The same universities, salaries of different positions should also follow the principle of difference, for those key positions or staff important posts on his remuneration should be higher than ordinary staff positions, which will help colleges and universities to attract and retain talent. Thirdly, the need to follow the principle of transparency. Universities pay system during the time of change, but also need to follow the principles of transparency, the so-called transparent, referring to the compensation plan and assessment appraisals and so must be transparent, so it is possible to play a supervisory role.

Improve the Salary System. At this stage, the wages of staff, many colleges and universities in China are pay for performance, the so-called performance salary, that is in addition to the basic wages and grade salary, performance salary, allowance and so on, in fact, the wages can be divided into two parts, respectively is wage and performance wage security. The existence of the guarantee wages makes the staff of colleges and universities be able to guarantee the daily life, while the performance salary is to play the role of motivation. Of course, colleges and universities should also clear staff two wage type proportion, otherwise unable to safeguard staff's daily life, or cannot play the role of incentives. According to the relevant practice, the proportion of performance pay in total wages is about $30 \%$ more reasonable.

Improve the Assessment System. With a sound system of work, in theory, it is necessary to ensure that the daily lives of the staff, but also to play a role in stimulating. However, performance salary payment, totally need according to the assessment results to determine, if the assessment 
result is not fair, just, then you cannot really reflect out university employee contributions and personal ability of strength. At this stage, a lot of colleges and universities are also for the staff of the work of the assessment, but the establishment of the assessment index is not complete enough, this cannot be a comprehensive assessment of the ability of a professional. Therefore, colleges and universities should stand in the global angle of view of, and improve the appraisal system, re-establishment of evaluation standard, make to each and every staff of comprehensive assessment, and in process of assessment should follow the principles of fairness, impartiality and openness.

Optimize the Allocation System. Allocation of pay is also very important, in the past, the most common distribution in addition to wages, as well as bonuses and a variety of benefits, etc., and some excellent teachers will have an allowance. With the development of social economy, the distribution system should be changed, in this regard, we can learn the enterprise, give the staff salary distribution. Then it is time to pay attention to material incentives, thus improving the ability of the whole staff, but also help to help retain and attract talents in Colleges and universities.

Establish Supporting System. In order to smoothly reform colleges and universities' salary system and implement the reformed salary system, it is also necessary to establish a supporting environment and create a good external environment, which needs the effort of colleges and the government. In terms of the government, they can formulate related laws and regulations to promote the reform of salary system at colleges and universities. For colleges and universities, they should determine the specific responsibilities of each post and the salary level accordingly.

At present, public institutes have reformed the pension insurance system, and under such background, it is necessary to reform colleges and universities' salary system to make it more conform with the current situation. Thus, colleges and universities should reform the salary system according to their own situation to make it more conform with college staffs' demands.

\section{References}

[1] Guan Peijun. Reflection on Reforming Colleges and Universities' Personnel System in the New Times [J]. Education Research, 2014, 12:72-80.

[2] Xiao Feng. On the Reform of Colleges and Universities' Salary System based on Reforming Pension Insurance System [J]. Human Resource Development, 2015, 22:53-54.

[3] Research Group of the Institute of Fiscal Science, Ministry of Finance, Su Ming, Yang Liangchu, Zhang Xiaoyun, Wang Ligang, Cheng Yu. Research into Reforming Pension Insurance System at Public Institutes in China [J]. Economic Research Reference, 2012, $52: 3-25$.

[4] Gao Herong, Zhang Aimin. On the Improvement of Reforming Pension Insurance System at China's Public Institutes [J]. Journal of Beijing Normal University (social science edition), 2014, 04:151-158.

[5] Cheng Yi. Analysis of Problems Existing in the Reform of Colleges and Universities' Salary System and Countermeasures [J]. China Electric Power Education, 2010, 16:172-174.

[6] Gui Shixun. Reflection on Reforming Pension Insurance System of China's Public Institutes [J]. Journal of East China Normal University (Philosophy and Social Science Edition), 2010, 03:71-75.

[7] Jiang Limin. On the Design of Colleges and Universities' Salary System [J]. Journal of Zhejiang Wanli University, 2006, 04:86-88.

[8] Li Zhongying, Lu Jun, Liu Yan. Analysis of the Current Status of Colleges and Universities' Salary System and Reform [J]. Maritime Education Research, 2013, 01:110-111.

[9] Zang Xingbing, Li Jia. The Journey of Reforming Salary System of China's Colleges and Universities [J]. Journal of Kunming University of Science and Technology (social science edition), 2013, 02:22-28. 
[10]Zeng Xueshan, Song Yi. Research into the Problems in the Salary System of China's Colleges and Universities and Countermeasures [J]. Journal of Jiangxi Normal University (Philosophy and Social Science Edition), 2007, 02:119-123. 